\title{
Bioremediation of mercury: not properly exploited in contaminated soils !
}

Khandaker Rayhan Mahbub ${ }^{1,2,3,4 *}$, Md Mezbaul Bahar ${ }^{2,3}$, Maurizio Labbate ${ }^{1}$, Kannan Krishnan ${ }^{2,3}$, Stuart Andrews $^{5}$, Ravi Naidu', ${ }^{2,3}$, Mallavarapu Megharaj ${ }^{2,3}$

1. School of Life Sciences \& the i3 Institiute, University of Technology Sydney, Ultimo NSW 2007, Australia

2. Global Centre for Environmental Remediation, Faculty of Science and Information Technology, The University of Newcastle, Callaghan, NSW 2308, Australia

3. Cooperative Research Centre for Contamination Assessment and Remediation of the Environment (CRC-CARE), Mawson Lakes, Adelaide SA 5095, Australia

4. Bangladesh Council of Scientific and Industrial Research, Dhanmondi, Dhaka 1205, Bangladesh

5. University of South Australia, Adelaide, SA 5001, Australia

*Author for correspondence: Khandaker Rayhan Mahbub

Global Centre for Environmental Remediation

ATC Building, Level 1

Faculty of Science and Information Technology

The University of Newcastle

University Drive, Callaghan NSW 2308, Australia

Mob: +61 404022697

Email: KhandakerRayhan.Mahbub@uon.edu.au; Krmjissan@gmail.com

\begin{abstract}
Contamination of land and water caused by heavy metal mercury ( $\mathrm{Hg}$ ) poses a serious threat to biota worldwide. The seriousness of toxicity of this neurotoxin is characterized by its ability to augment in food chains and bind to thiol groups in living tissue. Therefore, different remediation approaches have been implemented to rehabilitate $\mathrm{Hg}$ contaminated sites. Bioremediation is considered as cheaper and greener technology than the conventional physico-chemical means. Large scale use of $\mathrm{Hg}$ volatilizing bacteria are used to clean up $\mathrm{Hg}$ contaminated waters, but there is no such approach to remediate $\mathrm{Hg}$ contaminated soils. This review focuses on recent uses of $\mathrm{Hg}$ resistant bacteria in bioremediation of mercury contaminated sites, limitation and advantages of this approach and identifies the gaps in existing research.
\end{abstract}

Key words: Soil, water, monitoing, mer operon. 


\section{Introduction}

Mercury $(\mathrm{Hg})$ is a global threat to human and environmental health because of its toxicity, mobility and long residence time in the atmosphere. This metallic element has been ranked $3^{\text {rd }}$ in the "priority list of hazardous subtances" by the Agency for Toxic Substances and Disease Registry (ATSDR 2015). Recent reports show that the majority of global $\mathrm{Hg}$ is released by natural processes such as oceanic emission and biomass burning (combustion of organic substances) whereas the other significant portion is released due to human activities predominantly by mining, metal manufacturing and fossil fuel burning (Nelson et al. 2012; Pirrone et al. 2010; Serrano et al. 2013).

In both terrestrial and aquatic systems, $\mathrm{Hg}$ exists in elemental, inorganic, and organic forms. Inorganic $\mathrm{Hg}$ has two valences, +1 and +2 , mostly found as salts (Wang et al. 2004). $\mathrm{Hg}$ with valence +2 is more widely spread in the environment. In anaerobic sediments and water logged soils, methylation is the most toxic tansformation which resluts in formation of organic - monomethyl or dimehtyl $\mathrm{Hg}(\mathrm{MeHg})$, which are neurotoxins. Due to inherent toxicity of both inorganic and organic forms of $\mathrm{Hg}$, the US Environmental Protection Agency (EPA) recommends a limit of $2.0 \mu \mathrm{g} \mathrm{L}^{-1}$ in water (EPA 2016). In soils, these recommended precautionary $\mathrm{Hg}$ limits vary in different industrial countries from 6.6 to $3600 \mathrm{mg} \mathrm{kg}^{-1}$, depending on the land use (Mahbub et al. 2016c). Generally, the average background concentration of $\mathrm{Hg}$ in soil ranges from 0.03 to $0.1 \mathrm{mg} \mathrm{kg}^{-1}$ with an average value of $0.06 \mathrm{mg} \mathrm{kg}^{-1}$ (Wang et al. 2012). Recent reports shows that $\mathrm{Hg}$ can exert deleterious effects on soil health at concentrations even lower than current recommended safe limits, sometimes at background concentrations (de Vries et al. 2007; Mahbub et al. 2016b; Mahbub et al. 2016f; Tipping et al. 2010), which warrants more effective remediation technologies.

Being considered as the cheapest and most environmentally friendly technology, the application of bioremediation for cleaning up $\mathrm{Hg}$ from polluted areas has been applied widely in treating $\mathrm{Hg}$ loaded waste waters. There are many examples of successful pilot scale applications of $\mathrm{Hg}$ volatilizing bacteria for the removal of $\mathrm{Hg}$ from contaminated industrial waters (Velásquez-Riaño and Benavides-Otaya 2015; WagnerDöbler 2003; Wagner-Döbler 2013). The aim of the present work was to review current knowledge (a total of 793 articles recovered using a Scopus search between the years 2000 - 2016) on the $\mathrm{Hg}$ remediation with an emphasis on the bioremediation technologies in soil and their potential use in the detoxification of $\mathrm{Hg}$ contamination. We have identified that although $\mathrm{Hg}$ resistant $(\mathrm{HgR})$ bacteria are ubiquitous in terrestrial environments, there is almomst no knowledge about the application of HgR microorganisms as bio-control agents for remediating $\mathrm{Hg}$ contaminated soils.

\section{The mercury cycle in the environment}

Most of the mercury released to the atmosphere is gaseous elemental $\mathrm{Hg}^{0}$ which can travel a long distance from its origin for $6-12$ months before becoming deposited into aquatic or terrestrial environments. During atmospheric travel, the elemental $\mathrm{Hg}^{0}$ is oxidized to highly soluble toxic divalent $\mathrm{Hg}^{2+}$ by atmospheric oxidants such as bromine, ozone, $\mathrm{HClO}, \mathrm{HSO}^{3-}, \mathrm{OH}$ in fog and cloud droplets (Munthe 1992; Munthe and McElroy 1992). The oxidized $\mathrm{Hg}\left(\mathrm{Hg}^{2+}\right)$ subsequently accumulates in aquatic and terrestrial bodies. A small portion of atmospheric $\mathrm{Hg}^{2+}$ is reduced in the atmosphere by the reductant $\mathrm{SO}^{3-}$ or by photo-reduction to $\mathrm{Hg}(\mathrm{OH})_{2}(\mathrm{Ariya}$ et al. 2015; Munthe et al. 1991). Some of the deposited oxidized $\mathrm{Hg}^{2+}$ is reduced to $\mathrm{Hg}^{0}$ and goes back to the 
atmosphere. The major portion cycles through soils and waters, becoming transformed to more toxic organic forms and subsequently intoxicates organisms and concentrates up the food chain (Amos et al. 2013). The overall process of emission of $\mathrm{Hg}$ and its transformation in the environment is depicted in Figure 1.

The accumulation of oxidized $\mathrm{Hg}^{2+}$ from the atmosphere to soil $(60 \%)$ and waters $(30 \%)$ occurs mainly by wet deposition (Mason et al. 1994). In oceanic waters, $\mathrm{Hg}^{2+}$ undergoes a series of chemical and biological reactions which leads to volatilization of a major portion of $\mathrm{Hg}$ to the atmosphere; whereas a small amount is taken into the sediments. In terrestrial bodies, a smaller portion of $\mathrm{Hg}$ returns to the atmosphere in a reduced form and the major portion becomes permanently accumulated in soils. Mercury resistant microbial communities with a mer operon can produce a mercuric reductase enzyme which reduces soil $\mathrm{Hg}^{2+}$ to volatile less soluble $\mathrm{Hg}^{0}$ that returns to the atmosphere. In soil, a major portion of $\mathrm{Hg}$ is bound to soil organic matter (SOM), sulphide anions, soil minerals and clay particles (Mahbub et al. 2016b; Skyllberg 2012; Tazisong et al. 2012). In low pH soils $\mathrm{Hg}^{2+}$ is mainly complexed to the SOM, whereas in neutral to alkaline soils mineral components also offer complexation. Fulvic acid and humic acids play important roles in the complexation of $\mathrm{Hg}$ in soil (DunhamCheatham et al. 2015). The complexation of $\mathrm{Hg}^{2+}$ mainly acts through the $\mathrm{C}=\mathrm{O}, \mathrm{COO}^{-}$, and $\mathrm{O}-\mathrm{H}$ groups of organic matter (Ma et al. 2015). Therefore only a negligible amount of $\mathrm{Hg}(0.00001$ to $1.5 \%$ of total $\mathrm{Hg})$ is available in soil solution (Mahbub et al. 2016b) to be transported into resistant microbial cells and subsequent volatilization as $\mathrm{Hg}^{0}$. Hence most of the soil $\mathrm{Hg}$ accumulates and increases $\mathrm{Hg}$ load in terrestrial bodies which can subsequently transfer to the food chain. Apart from reduction and subsequent volatilization, methylation and formation of $\mathrm{HgS}$ are also evident in soil environments. Monomethyl $\mathrm{Hg}$ formation is favoured in low $\mathrm{pH}$ soil and dimethyl $\mathrm{Hg}$ formation is facilitated in neutral to alkaline soil (Stein et al. 1996). Formation of $\mathrm{HgS}$ is common in sulfidic soils which is less mobile and a less reactive form of $\mathrm{Hg}$ as a result of adsorption to iron sulphide and pyrite (Stein et al. 1996). Hg can also strongly complex with reduced sulphur groups in SOM in highly aerobic environments (Skyllberg et al. 2006). In addition to chemical reactions, HgS can also be produced aerobically under controlled $\mathrm{pH}$ as a result of microbial activity (Kelly et al. 2006; Kelly et al. 2007; Lefebvre et al. 2007).

The most important transformation of $\mathrm{Hg}$ in anoxic aquatic sediments is methylation which requires transfer of methyl ion $\left(\mathrm{CH}_{3}{ }^{-}\right)$by anaerobic sulphate reducing bacteria (SRB). The biotic methylation of $\mathrm{Hg}$ is the predominant mechanism for transformation but there is some evidence for abiotic transformation (Barkay and Wagner-Döbler 2005; Celo et al. 2006; Fitzgerald and Lamborg 2007; Fleming et al. 2006; Gårdfeldt et al. 2003). The physicochemical characteristics of water bodies ( $\mathrm{pH}$, ligands, sulphates, nutrients) and impact from anthropogenic activities play major roles in the formation of methyl $\mathrm{Hg}\left(\mathrm{CH}_{3} \mathrm{Hg}^{+}\right)$and maintaining the relative proportion of $\mathrm{Hg}^{2+}$ and $\mathrm{CH}_{3} \mathrm{Hg}^{+}$in aquatic environments. Methyl $\mathrm{Hg}(\mathrm{MeHg})$ is the only form of $\mathrm{Hg}$ which is augmented in the food chain (Celo et al. 2006) as a thiolate complex (Harris et al. 2003), where it represents 95\% of total $\mathrm{Hg}$ in the top predators of a food chain (Celo et al. 2006). Demethylation of MeHg is another important transformation process. Reductive demethylation converts $\mathrm{MeHg}$ to $\mathrm{Hg}^{0}$ where it is volatilized to the atmosphere; the reduction reaction is governed by $\mathrm{Hg}$ resistant anaerobic bacteria which produces organomercury lyase (OL) enzyme in $\mathrm{Hg}$ rich conditions. On the other hand oxidative demethylation produces $\mathrm{Hg}^{2+}$ in low $\mathrm{Hg}$ containing anaerobic environments, which then serves as a substrate for methylation. Photooxidation plays a major role in oxidative demethylation in low $\mathrm{MeHg}$ contaminated waters, whereas when 
MeHg contamination is high in sediments, microbial methylation plays the dominant role. The photolytic demethylation rate (due to formation of singlet oxygen generated by sunlight falling on dissolved organic matter) is faster when the MeHg species are bound to dissolved organics such as sulphur containing ligands in fresh waters, rather than inorganic bound $\mathrm{MeHg}$ found in marine waters (Zhang and Hsu-Kim 2010).

\section{Traditional approaches for mercury remediation from soil and water}

The primary concern of industries and regulatory agencies is to remediate $\mathrm{Hg}$ polluted soils and waters and reduce any potential risks of toxicity. Unlike organic pollutants, $\mathrm{Hg}$ cannot be mineralized. Therefore transformation of the toxic ionic and organic forms to less toxic or less reactive species such as elemental $\mathrm{Hg}$ or $\mathrm{Hg}$ sulphides (which are not accumulated into food chain) is becoming an essential approach for remediating $\mathrm{Hg}$ contaminated sites. Recent approaches for $\mathrm{Hg}$ remediation are summarised in Table 1. The traditional physicochemical processes of $\mathrm{Hg}$ remediation can produce large volumes of $\mathrm{Hg}$-loaded biomass, the disposal of which is not always environmentally friendly and may be expensive (Wagner-Döbler 2013). These are briefly described in the following sections.

\section{Treatment technologies for water}

Precipitation is the most common technology for remediating $\mathrm{Hg}$ contaminated ground water and waste water. The principle of precipitation is to mix a chemical precipitant (commonly sodium sulphide in the case of $\mathrm{Hg}$ ) into the water, coagulating the soluble form of inorganic $\mathrm{Hg}$ to insoluble $\mathrm{HgS}$ under controlled neutral to alkaline pH condition (Findlay and McLean 1979; Hansen and Stevens 1993; O'rear et al. 2015). The precipitated $\mathrm{HgS}$ is later separated by filtration or clarification. Another precipitation approach uses lignin derivatives to form lignin-Hg complexes which are removed by gravity settling in a clarifier. The disadvantages of precipitation approaches are that the precipitated sludge may be hazardous, requiring further solidification/stabilization treatment prior to disposal. Excessive use of sulphides can form soluble $\mathrm{HgS}_{2}$ species which can leach into ground water from disposed sludge (USEPA 1997).

$\mathrm{Hg}$ is also removed from water by adsorption onto granular activated carbon or sulphur-impregnated activated carbon and functionalized multiwall carbon nanotubes which are packed on a column through which contaminated water is passed (Asasian et al. 2012; Hadavifar et al. 2014; Musmarra et al. 2013). Prior to adsorption, pre-treatment technologies such as flocculation, precipitation, settling, and filtration may be required. Fouling and plugging caused by suspended solids, dissolved organic compounds and biological growth are limitations of this approach.

Microfiltration and ultrafiltration have been used on small scales to physically separate $\mathrm{Hg}$ after it has been precipitated from wastewaters (Urgun-Demirtas et al. 2012). This approach has disadvantages similar to adsorption when suspended solids, organic compounds, colloids, and other contaminants can cause membrane fouling.

Apart from these physical separation methods, bioremediation of $\mathrm{Hg}$ has been successfully implemented to remove $\mathrm{Hg}^{2+}$ from contaminated waters. Bioremediation is mainly based on two approaches - microbial volatilization and bio-sorption (Wagner-Döbler 2003). Microbial volatilization utilizes activities of a number of 
genes in the bacterial "mer" operon which transports $\mathrm{Hg}^{2+}$ and organic $\mathrm{MeHg}$ into the bacterial cytoplasm where it is then reduced to elemental $\mathrm{Hg}^{0}$ by mercuric reductase enzyme (MerA) and subsequently volatilised from the cell. (Mahbub et al. 2016a; Santos-Gandelman et al. 2014). Although merA is the dominant pathway for volatilization, mer independent volatilization is also evident in some studies (Wiatrowski et al. 2006a).

Live or dead microbial biomass from bacteria, fungi or algae has been used for bio-sorption of volatilized $\mathrm{Hg}^{0}$ to restrict it from re-exposure to the atmosphere (Ahluwalia and Goyal 2007; François et al. 2012). This is achieved by designing a packed bed bioreactor where $\mathrm{Hg}$ resistant bacterial biofilm is grown on porous carrier material to trap $\mathrm{Hg}^{0}$ produced from microbial reduction reactions (Wagner-Döbler 2003). Under certain conditions some resistant bacteria can secrete exo-polymers that adsorb $\mathrm{Hg}^{2+}$ (François et al. 2012). Precipitation of $\mathrm{Hg}^{2+}$ as insoluble $\mathrm{HgS}$ (cinnabar) is a potential bioremediation technology under aerobic conditions but not under anaerobic conditions, because in anoxic environment the precipitated $\mathrm{HgS}$ is taken up by SRB and methylated (Lefebvre et al. 2007). Since the microbial reduction of $\mathrm{Hg}^{2+}$ to $\mathrm{Hg}^{0}$ is an energy driven metabolic process, continuous nutrient feeding and maintaining optimal conditions for microbial growth is necessary. Moreover, high concentration of contaminants may inhibit microbial activity and the bioreactor effluent normally requires further precipitation treatment. Despite some limitations, this technology has been considered as a cheaper and greener technology compared to previously described technology to clean up $\mathrm{Hg}$ contaminated waste waters (Wagner-Döbler 2013).

\section{Treatment technologies for soil}

For remediating $\mathrm{Hg}$ contaminated soils, common strategies currently in use include -

- extraction of $\mathrm{Hg}$ from soil to lower the bioavailable portion within the soil,

- immobilization of reactive forms of $\mathrm{Hg}$ by encapsulation to reduce its mobility in soil,

- thermal treatment to volatilize as elemental $\mathrm{Hg}$ and

- vitrification (immobilization of $\mathrm{Hg}$ containing waste into a glass matrix)

Physical separation of $\mathrm{Hg}$ from soil by soil washing is a widely used approach which sometimes combines chemical extraction (with acid or alkali and chelating agents) when $\mathrm{Hg}$ is strongly bound to soil organics and when the soil clay content is 30 to $50 \%$ and the $\mathrm{Hg}$ content is more than $260 \mathrm{mg} / \mathrm{kg}$ (Dermont et al. 2008b; Wang et al. 2012). This technology is easily applied and has been established in several industries, but the cost of chemicals increases processing costs. Moreover, strongly complexed $\mathrm{Hg}$ is difficult to remove in this process requiring longer processing times and multiple processing steps, and soil cations may interfere with the extraction process. Unfortunately, soil washing generates a large volume of $\mathrm{Hg}$ containing waste water which is difficult to recycle (Abumaizar and Smith 1999).

Hg can be stabilized and encapsulated in a rigid and durable matrix (Cho et al. 2014a; López et al. 2015). Stabilization/solidification is the most utilised in situ approach for remediation of $\mathrm{Hg}$ contaminated soils where the Hg load is less than $260 \mathrm{mg} / \mathrm{kg}$ (Wang et al. 2012). This process can decrease the bioavailable portion of soil $\mathrm{Hg}$ and slow the release of $\mathrm{Hg}$ to surface and ground waters. Phosphates, lime, fly ashes, alumino-silicates, powder re-activated carbon, ceramics and sulphur polymer are widely used stabilizing agents (Cho et al. 2014b; López et al. 2015; Zhang et al. 2015). This strategy is common in the USA and there is no risk of secondary 
waste; but leachability, increased volume of the treated material, interference by soil organic matter and longterm monitoring are the limiting factors (Guo et al. 2011).

Another important in situ technology is immobilization of $\mathrm{Hg}$ by sulphur containing ligands, reducing agents and absorbing agents that decreases mobility, toxicity and solubility of reactive forms of $\mathrm{Hg}$ in soil (Bower et al. 2008; Kot et al. 2007). Adding reduced sulphur to $\mathrm{Hg}$ containing soil is a method to precipitate $\mathrm{HgS}-$ which is relatively insoluble and less volatile than other forms of $\mathrm{Hg}$. Soil contaminated with $2300 \mathrm{mg} / \mathrm{kg} \mathrm{Hg}$ has been treated by this method (Piao and Bishop 2006). Field scale use of this approach has been successfully applied (Zhuang et al. 2004). The advantages of this approach are that the remediated soil can be re-vegetated and the approach is applicable to large sites. But the amount of $\mathrm{HgS}$ loaded in the soil (which may serve as substrate for methylation) and long term monitoring are disadvantages of this approach.

High temperature with reduced pressure has been employed as thermal treatment to volatilize $\mathrm{Hg}$ from soil and to condense the $\mathrm{Hg}$ vapour to liquid form (Busto et al. 2011; Ma et al. 2014a) but this process is not suitable for organic or clay rich soil, the capital cost for maintaining this approach is very high, and the treated soil is not suitable for agricultural re-use as the high temperature alters soil quality (Dermont et al. 2008a). Moreover, hazardous gas produced from the process requires further treatment (Mulligan et al. 2001). Vitrification has also been used to immobilize soil bound $\mathrm{Hg}$ mainly in organic rich soils in situ and ex situ. This approach is not cost effective for soils with excessive organic content, high moisture, high metal content and halogens (USEPA 2007). Moreover, these two approaches are still at the experimental stage for field use.

Other than these physico-chemical approaches, biological methods such as phytoremediation has recently been introduced to remediate $\mathrm{Hg}$ from contaminated soils. Phytoremediation works in three ways - phytostabilization, phyto-extraction and phyto-volatilization (Tangahu et al. 2011). For example, it has been demonstrated that willow species stabilize $\mathrm{Hg}$ by adsorption and accumulation in the root system which inhibits the level of bioavailable $\mathrm{Hg}$ in the rhizosphere (Wang et al. 2005). Certain plant species such as Polypogon monospeliensis, Brassica juncea, Pteris vittata can accumulate Hg from contaminated soils. These plants accumulate $\mathrm{Hg}$ in their roots and shoots which are subsequently harvested, removed to an isolated area and then incinerated (Su et al. 2008; Su et al. 2007). However, recent studies show that the efficiency of Hg sequestration in plant is low because it is restricted to only leached and bioavailable $\mathrm{Hg}$ (Pant et al. 2010). Therefore, some strategies like compost amendment have been introduced recently to increase soluble $\mathrm{Hg}$ portion in soil which would be subjected to phyto-extraction (Smolinska 2015).

Additional approaches have included the modification of plants such as Oryza sativa with $\mathrm{Hg}$ reductase gene (merA) from bacteria. These genetically engineered plants were observed to reduce ionic $\mathrm{Hg}$ to less toxic elemental $\mathrm{Hg}$ which was subsequently volatilized (Heaton et al. 2003) leading to a secondary pollution problem. The future application of phytoremediation of $\mathrm{Hg}$ is limited by the scarcity of suitable hyper-accumulator resistant plant species, and the disposal of contaminated plant biomass (Xu et al. 2015). 
Although microbial volatilization has been successfully applied to remediate $\mathrm{Hg}$ contaminated waters, there is no evidence of small or large scale utilization of this approach to clean up contaminated soils except our recent study (Mahbub et al. 2016f), where successful removal of approximately $60 \%$ of soil bound $\mathrm{Hg}$ from a contaminated site was achieved with bio-augmentation and nutrient amendment. The study also demonstrated better growth of lettuce and cucumber in the bio-augmented soils. However, the application of bio-augmentation is limited in soil due to some or all of the following issues:

- $\quad$ poor bioavailability of $\mathrm{Hg}$ in soil,

- presence of mixed contaminants which may interfere with the metabolic activity of $\mathrm{Hg}$ resistant microorganisms,

- $\quad$ inadequate supply of nutrients and

- $\quad$ poor biochemical potential for effective bioremediation (USEPA 2007).

\section{Importance of bacterial mer operon in bioremediation of mercury}

\section{Functions of mer operon}

$\mathrm{Hg}$ resistant bacterial species contain a cytoplasmic enzyme "mercuric reductase", encoded by the mer operon which reduces soluble $\mathrm{Hg}^{2+}$ to insoluble elemental $\mathrm{Hg}^{0}$ (Adeniji 2004) which subsequently diffuses from the cell (Wagner-Döbler 2003). Volatilization of $\mathrm{Hg}$ from the bacterial cell is a well-known resistance mechanism attributed to the genetic determinant, the mer operon (Felske et al. 2003; Nies 1999; Summers and Lewis 1973) The mer operon has been found in a wide range of Gram-negative and Gram-positive bacteria (Dash and Das 2012) where it can be located on plasmids (Brown 1985; Griffin et al. 1987; Rådström et al. 1994), chromosomes (Inoue et al. 1991; Mahbub et al. 2016e), transposons (Kholodii et al. 1993) or integrons (Liebert et al. 1999). A number of bacteria have been reported to have the mer operon system, including Shigella flexneri, Pseudomonas aeruginosa, P. putida, P. stutzeri, P. fluorescence, Klebsiella pneumonia, Morganella morgani, Xanthomonas, Achromobacter, Acinatobacter calcoaceticus, Serratia marcesense, Mycobacterium marinum, Staphylococcus aureus, Bacillus sp., Enterobacter, Sphingobium sp., Sphingopyxis sp. Luteimonas sp., Psychrobacter sp. (Cabral et al. 2012; Chien et al. 2012; Giri et al. 2014; Mahbub et al. 2016a; Mahbub et al. 2016d; Pepi et al. 2013; Singh et al. 2011; Sinha and Khare 2012; Sinha et al. 2012). The presence of the mer operon has also been detected in thermophilic bacteria and archaea such as Brevibacillus sp., Anoxybacillus sp. and Geobacillus kaustophilus isolated from $\mathrm{Hg}$ rich geothermal springs and deep ocean (Barkay et al. 2010; Sar et al. 2013).

The mer operon is probably of ancient evolutionary origin and it is highly conserved in bacteria (Wang et al. 2004). There are two types of mer determinants; narrow-spectrum and broad-spectrum. The narrow-spectrum mer determinant confers tolerance to inorganic $\mathrm{Hg}$ only whereas the broad spectrum mer determinant is for resistance to both organic and inorganic forms of $\mathrm{Hg}$ (Bogdanova et al. 1998; Misra et al. 1984; Silver and Phung 1996). This is a positively regulated operon that consists of

- operator and promotor region, encodes specific regulatory protein MerR, 
- $\quad$ uptake proteins at the downstream of operator-promotor region (translated by structural genes) namely MerT, MerP and MerC, MerF, MerG, MerE,

- $\quad$ reduction enzyme MerA and

- lyase enzyme MerB in broad spectrum resistant organisms (Table 2).

The transcription of the "mer" operon is suppressed if no $\mathrm{Hg}$ is present because the repressor MerR binds to the promoter region and inhibits transcription. When $\mathrm{Hg}$ is available in inducible concentrations, it binds to the MerR repressor and releases it from the promoter and transcription begins. At the protein sequence level, MerR's closest homolog is $\mathrm{ZntR}$, the regulator of $\mathrm{Zn}^{2+}$ homeostasis in many bacteria (Summers 1986). Another regulatory gene in the mer operon, merD, encodes a protein that in small concentrations is antagonistic to MerR by competing for the promotor-operator region through weak binding (Nucifora et al. 1989).

Although $\mathrm{Hg}$ can get into bacterial cells at the pico-molar level without any transport proteins, there is a dedicated specific $\mathrm{Hg}$ transport machinery which utilises the merT, merP, $\operatorname{mer} C$, $\operatorname{mer} F$ and $\operatorname{merE}$ genes (Nascimento and Chartone-Souza 2003). Hg binds to the periplasmic space with MerP and is then transported across the membrane using proteins encoded by the $\operatorname{mer} T$ or $\operatorname{merF}$ genes. Both $\operatorname{mer} T$ and $\operatorname{mer} P$ are required for full expression of $\mathrm{Hg}$ resistance, but loss of merP is less deleterious than loss of merT. In contrast, mutating merC has no effect on $\mathrm{Hg}^{2+}$ resistance. In the cytosol, $\mathrm{Hg}^{2+}$ is transferred from MerT to MerA.

Within the mer operon the merA gene is of greatest significance being translated into a mercuric reductase, which catalyses the NADPH dependent reduction of thiol-avid $\mathrm{Hg}^{2+}$ to $\mathrm{Hg}^{0}$ and expels toxic $\mathrm{Hg}$ out of the cell. The broad spectrum mer operon containing merB encodes the organomercurial lyase enzyme which breaks the carbon- $\mathrm{Hg}$ covalent bond present in organic $\mathrm{Hg}$ transported into the cell by MerE or MerG activity to produce $\mathrm{Hg}^{2+}$ (Curran and Franza Jr 1991; Summer and Silver 1978; Wang et al. 2004) which is then reduced to $\mathrm{Hg}^{0}$ by the enzyme mercuric reductase (merA) with NADPH, -SH compounds and FAD (Schottel 1978). The enzymatic reaction takes place within minutes. The reduced $\mathrm{Hg}$ diffuses from the cell and can readily be volatilized. This volatilized $\mathrm{Hg}$ either can be retained in a packed bed bioreactor consisting of inert porous carrier material such as siran, pumice, synthetic fibres, activated carbon, wood chips, cellulose fibres (Nascimento and Chartone-Souza 2003) or is trapped in the remediating microorganisms intra or extracellularly either by bioaccumulation or biosorption (Sinha et al. 2012).

\section{Applications of mercury resistant bacteria in bioremediation}

As a result of understanding the mechanisms of the mer operon, a number of strategies have evolved exploiting $\mathrm{Hg}$ resistant microorganisms and cloned mer genes with various degrees of success. The most frequently applied approach is to pass $\mathrm{Hg}$ contaminated water through a bioreactor containing resistant bacteria which volatilize $\mathrm{Hg}^{2+}$ that is subsequently trapped in activated carbon or some other suitable material (USEPA 2007; VelásquezRiaño and Benavides-Otaya 2015). A pilot plant bioreactor for treating wastewaters from a chlor-alkali plant was designed with a packed bed biofilm consisting of both $\mathrm{Hg}$ resistant and $\mathrm{Hg}$-volatilizing bacterial biofilm (Wagner-Döbler 2003). The packed bed was composed of an inert porous carrier material and the biofilm included seven different species of $\mathrm{Hg}$ resistant Pseudomonas. The bacteria present in biofilms reduced $\mathrm{Hg}^{2+}$ to volatile $\mathrm{Hg}^{0}$ which were subsequently trapped in the carrier material. During the whole testing period of eight 
months this bioreactor remediated $98 \%$ of $\mathrm{Hg}$ in the effluent $(28.8 \mathrm{~kg}$ out of $29.3 \mathrm{~kg} \mathrm{Hg}$ ). The volatile $\mathrm{Hg}$ collected in the bioreactor was recovered by distillation (Wagner-Döbler 2003).

In another approach, the wastewater and a $\mathrm{Hg}$ resistant bacterial culture were mixed in an aerated bioreactor where $\mathrm{Hg}$ reducing bacteria transformed $\mathrm{Hg}^{2+}$ to volatile $\mathrm{Hg}^{0}$ gas which was trapped in an activated carbon filter (Deckwer et al. 2004). An ion exchange membrane bioreactor (IEMB) was developed recently which was coupled with a cation exchange membrane and a bioreactor containing $\mathrm{Hg}$ volatilizing bacteria to remove low levels of $\mathrm{Hg}$ in drinking water and high levels in industrial water (Oehmen et al. 2014)

Other than using external trapping material, another method for $\mathrm{Hg}$ bioremediation requires the accumulation of volatilized $\mathrm{Hg}$ in the remediating cells. A $\mathrm{Hg}$ resistant strain of Enterobacter which completely reduced $\mathrm{Hg}^{2+}$ to volatile $\mathrm{Hg}^{0}$ and subsequently accumulated the volatilized $\mathrm{Hg}$ in the cytoplasm has been reported (Sinha and Khare 2012). This kind of approach has been reported by other authors where the resistant bacteria have been immobilized onto alginate beads or biofilms (Anthony 2014; Chien et al. 2012; Dash and Das 2015; Tariq and Latif 2014).

For the removal of $\mathrm{Hg}$ from sediments a combination of chemical leaching by hydrochloric acid-ferric chloride solution and subsequent seeding by a $\mathrm{Hg}$ resistant strain Pseudoalteromonas haloplaktis M1 has been reported; this process resulted in removal of $85 \%$ of $\mathrm{Hg}$ from Minamata Bay sediments (Nakamura et al. 1999). A similar approach was utilized by Pepi et al. (2011) who developed a laboratory scale pilot plant to treat contaminated sediment. Biofilm of Pseudomonas sp. and Psychrobacter sp. were formed on pumice particles packed in 100 $\mathrm{ml}$ glass column. The immobilized cells completely volatilized $\mathrm{Hg}$ from sediments leachate which was trapped by $\mathrm{KMnO}_{4}$ added at outflow. Utilization of immobilized resistant bacterial cells to remediate $\mathrm{Hg}$ contaminated sediment leachates is evident in several other laboratory scale pilot studies (Cabral et al. 2013; Jafari et al. 2015; Pepi et al. 2013).

To remediate radioactive $\mathrm{Hg}$ contaminated waste a Deinococcus radiodurans strain was transformed with mer gene from E. coli (Brim et al. 2000). Deinococcus radiodurans is well known for its radiation resistant characteristics (Daly et al. 1994) and the recombinant strain engineered with mer harbouring plasmid became $\mathrm{Hg}$ resistant also. This recombinant strain reduced $\mathrm{Hg}^{2+}$ to volatile $\mathrm{Hg}^{0}$ in the presence of $50 \mathrm{~Gy} / \mathrm{h}$ of gamma radiation (Brim et al. 2000). Deinococcus geothermalis, a thermophilic radiation resistant strain was also engineered to harbour mer operon to use in $\mathrm{Hg}$ remediation in high temperature radioactive $\mathrm{Hg}$ contaminated sites (Brim et al. 2003).

Since contaminated sites contain a range of pollutants in addition to $\mathrm{Hg}$, genetic engineering has been used to develop multi-metal resistant bacterial strains with ability to withstand mixtures of environmental pollutants including other heavy metals. For example, a heavy metal resistant Cupriavidus metallidurans was transformed with $\operatorname{mer} B$, merG, merA and other mer genes that made the strain broad spectrum Hg resistant superbug which could completely volatilize $0.15 \mathrm{M} \mathrm{Hg}$ from solution contaminated with other metals, such as chromium and copper (Rojas et al. 2011). In another approach, a Bacillus cereus strain having Hg bio-sorption properties was transformed with the mer operon which made the transgenic strain capable of volatilizing and simultaneous precipitating $\mathrm{Hg}$ as $\mathrm{HgS}$ and resulting in $100 \%$ removal of $\mathrm{Hg}$ from solution (Dash and Das 2015) 
In addition to the application of MerA, there are applications of MerR in $\mathrm{Hg}$ remediation. A temperature responsive biopolymer has been reported for the remediation of $\mathrm{Hg}$ from contaminated water without volatilization. The bacterial MerR protein which has high affinity to $\mathrm{Hg}$ was extracted from a genetically engineered E. coli and fused to elastin like polypeptides for the formation of highly $\mathrm{Hg}$ specific biopolymer. This biopolymer reduced $\mathrm{Hg}$ concentration to background level (Kostal et al. 2003).

\section{Importance of mer operon in monitoring of environmental mercury}

To set up a successful bioremediation strategy it is important to have an appropriate monitoring system which measures the bioavailable fraction of a pollutant in the environment. A number of classical analytical methods are available for the detection and quantification of $\mathrm{Hg}$ from environmental and biological samples. The most widely used techniques are atomic absorption spectrophotometry (AAS), cold-vapour atomic flame absorption spectroscopy (CVAFS) (BáStockwell and TáCorns 1995), atomic emission spectroscopy (AES) (Jamoussi et al. 1995) and inductively coupled plasma mass spectrometry (ICP-MS) (Hintelmann et al. 2000). These methods are highly sensitive and characterized by low detection limits but the instrumentations are very expensive, require trained operators and laborious sample preparation procedures. Furthermore they cannot be used in field experiments (Bontidean et al. 2004). Some good alternatives to these analytical techniques are electrochemical methods (Turyan and Mandler 1993) such as ion selective electrodes (IES), anodic stripping voltammetry (ASV), potentiometric stripping analysis (PSA), current stripping chronopotentiometry (CSP) and differential pulse voltammetry (DPV). The disadvantage of all these methods is that they cannot detect the bioavailable $\mathrm{Hg}$ concentration because the $\mathrm{Hg}$ can be in various valences and complexes.

Quantification of bioavailable $\mathrm{Hg}$ is significant because it is the fraction that causes toxicity to plants and animals and is the substrate for biotic methylation and reduction. Information about the concentration of bioavailable $\mathrm{Hg}$ is critical for the management of $\mathrm{Hg}$ contamination. To detect and quantify the bioavailable $\mathrm{Hg}$ in environmental samples, microbial biosensors have been used. A biosensor combines a biological recognition element (biochemical receptor) and a suitable transduction element that can provide specific quantitative and semi-quantitative analytical information about the bioavailable metal. The recognition element can be an enzyme, whole bacterial cell, DNA or antibody and the transducer may be electrical, optical or thermal (Turdean 2011). For the detection of $\mathrm{Hg}$, whole cell bacterial biosensors have been constructed to contain a reporter plasmid that carries a fusion of merR regulatory region and the $\operatorname{lux} C D A B E$ operon from bioluminescent bacteria such as Aliivibrio fischeri and Photbacterium luminescens The combination of these genes in a suitable bacterial host can quantitatively responds to $\mathrm{Hg}^{2+}$ and can be detected through production of bioluminescence (Rasmussen et al. 2000) Corbisier et al. 1994). Since sensing of $\mathrm{Hg}$ occurs in the cytoplasm it has been established that biosensors detect the concentration of $\mathrm{Hg}$ available for binding the internal MerR protein. In biosensors for organic $\mathrm{Hg}$, the biochemical receptor carries an additional merB gene encoding the enzyme organomercurial lyase that cleaves the $\mathrm{C}-\mathrm{Hg}$ bond in organic $\mathrm{Hg}$. When organic $\mathrm{Hg}$ is present in the cytoplasm, the organomercurial lyase enzyme cleaves the bond and produce $\mathrm{Hg}^{2+}$ which then binds to merR gene and induces the expression of the reporter gene (Figure 2) (Barkay and Wagner-Döbler 2005). The MerR protein is the most common sensing element in both types of biosensors and the reporting elements can be bacterial 
luminescence $(l u x)$, green fluorescence protein $(g f p), \beta$-galactosidase (lacZ) or firefly luciferase $(l u c F F)$ (Hakkila et al. 2004; Hansen and Sørensen 2000).

A recombinant strain of $E$. coli MC1061 containing mer-lucFF gene fusion was used in a sensor which could detect $\mathrm{Hg}$ from soil sediment samples within a $2 \mathrm{~h}$ incubation period followed by $30 \mathrm{~min}$ settling time (Lappalainen et al. 2000). The same strain containing the sensor was reported to respond to $\mathrm{HgCl}_{2}$ with maximum detection limit $0.2 \mathrm{mg} / \mathrm{L}$ (Ivask et al. 2002). Recombinant E. coli (Hakkila et al. 2002) containing merR and luxCDABE from Photorhabdus luminescens was immobilized on multimode optical fibres. The bioluminescent response of this biosensor started at $0.001 \mathrm{mg} / \mathrm{L}$ and reached a maximum of $0.03 \mathrm{mg} / \mathrm{L} \mathrm{Hg}^{2+}$ (Ivask et al. 2007). A number of green fluorescent protein ( $g f p$ ) based $\mathrm{Hg}$ biosensors have been reported (Hakkila et al. 2002; Priyadarshi et al. 2012). Fro example, an E. coli DH5 $\alpha$ biosensor was made with the merR gene derived from pDU1358 and the $g f p$ gene from plasmid pDB402 inserted into pLDR9 responded to 100$1700 \mathrm{nM}\left(21.2 \times 10^{-6} \mathrm{~g} / \mathrm{L}\right.$ to $\left.360 \times 10^{-6} \mathrm{~g} / \mathrm{L}\right)$ concentration of $\mathrm{Hg}^{2+}$, and was stable at very high concentrations of Hg (Priyadarshi et al. 2012).

Although microbial whole cell biosensors offer a convenient, effective, specific and reliable method for monitoring of bioavailable $\mathrm{Hg}$, there are some limitations such as slow response, low sensitivity and poor selectivity. Biosensors with immobilized cells may have measurement problems because of inappropriate attachment of $\mathrm{Hg}^{2+}$ to the cells. Another limitation of immobilized whole cell biosensors is their restriction to only aqueous sample (Rasmussen et al. 1997). In lakes where pico molar levels of $\mathrm{Hg}$ frequently occur many biosensors are unable to detect these concentrations. This is essential where fish have bioaugmented $\mathrm{Hg}$ and residual levels of $\mathrm{Hg}$ need to be determined (Selifonova et al. 1993). Sometimes availability of $\mathrm{Hg}^{2+}$ to MerR is reduced due to some negatively charged groups and ligands on the cell (Rasmussen et al. 1997), interference of environmental factors such as dissolved organic carbon, salinity and pH (Barkay et al. 1997) leading to reductions in the sensing range.

\section{Emerging technologies}

\section{mer operon independent bioremediation approaches}

A number of novel mechanisms for $\mathrm{Hg}$ bioremediation by volatilization have been reported where the reduction of $\mathrm{Hg}^{2+}$ was not due to mer operon regulated mercuric reductase enzyme activity, and the bacteria were sensitive to $\mathrm{Hg}$. Iron $\left(\mathrm{Fe}^{2+}\right)$ oxidizing $\mathrm{Hg}$ sensitive acidophilic thiobacilli Thiobacillus ferrooxidans was reported to reduce $\mathrm{Hg}^{2+}$ by cytochrome c oxidase activity, when the medium was supplemented with $\mathrm{Fe}^{2+}$ (Iwahori et al. 2000). Hg sensitive dissimilatory metal reducing bacteria Shewanella oneidensis MR-1, Geobacter sulfurreducens PCA and G. metallireducens GS-15 demonstrated reduction of $\mathrm{Hg}^{2+}$ to volatile $\mathrm{Hg}^{0}$ without mercuric reductase in the presence of ferrous iron. Noteworthy is the activity of these organisms occurs only in very low concentrations of $\mathrm{Hg}$. Since mer gene expression requires $\mathrm{nM}$ concentrations of $\mathrm{Hg}$, these $\mathrm{Hg}$ sensitive bacteria are useful for $\mathrm{Hg}$ remediation in anoxic conditions where inorganic $\mathrm{Hg}^{2+}$ concentrations is not as high as in oxic environments (Wiatrowski et al. 2006b).

In another study, the gas which was produced by an aerobic culture of Klebsiella pneumoniae grown in a broth culture without any heavy metals, when passed through a solution of mixed contaminants including $\mathrm{Hg}$, resulted 
in a yellow white precipitate containing $97 \%$ of the initial $\mathrm{Hg}$. The gas evolved contained organo-sulphur compounds which immobilized $\mathrm{Hg}$ in solution (Essa et al. 2006).

Metallothionein (mt) is a well-known cysteine rich, low molecular weight metal binding protein that can sequester heavy metals in a biologically non-reactive form (Le et al. 2016). The metal sequestration property of metallithionein was utilized in $\mathrm{Hg}$ remediation by transforming a $\mathrm{Hg}$ sensitive $E$ coli with $m t$ gene which subsequently became resistant to $\mathrm{Hg}$ and could intracellularly accumulate approximately $100 \mu \mathrm{M} \mathrm{Hg}$ from solution (Ruiz et al. 2011).

\section{Application of nanotechnology}

Recently some endeavours have been taken to exploit nanoparticles for $\mathrm{Hg}$ sequestration from contaminated streams. A novel adsorbent, Thiol Self-Assembled Monolayers on Mesoporous Silica (Thiol-SAMMS) was developed which consisted of a nano-porous ceramic substrate with a high surface area made functional by a monolayer of thiol groups. The thiol functional groups bind with $\mathrm{Hg}$ and immobilize it (Mattigod et al. 2007). Colloidal gold nanoparticles, stabilized iron sulphide nanoparticles and Gymnemic Acid-Chitosan nanoparticles have also been utilized as Hg scavengers from water and sediments (Minu et al. 2015; Ojea-Jiménez et al. 2012; Xiong et al. 2009). A Hg resistant Enterobacter strain has been reported which exhibited a novel property of $\mathrm{Hg}$ immobilization by synthesis of nanoparticles $\mathrm{Hg}$. The strain could intracellularly synthesise uniform sized 2-5 $\mathrm{nm}$, spherical and monodispersed $\mathrm{Hg}$ nanoparticles in low $\mathrm{Hg}$ containing solution which prevented the reduced $\mathrm{Hg}$ from being volatilized (Sinha and Khare 2011).

\section{Future directions}

Bioremediation is considered a greener and cheaper technology to scavenge $\mathrm{Hg}$ from contaminated sites compared to physico-chemical means. Although a number of endeavours have been made to implement bioremediation approaches to clean up $\mathrm{Hg}$ contaminated waters, there is not enough evidence of the application of $\mathrm{Hg}$ resistant bacteria to remediate $\mathrm{Hg}$ contaminated soils. As soil is the reservoir of the major portion of $\mathrm{Hg}$ contamination it is mandatory to study the viability of the bioremediation technology. Soil organic matter, clay, minerals and other complex soil ligands determines the fate and mobility of $\mathrm{Hg}$ in soil, which is crucial for evaluating the implementation of bioremediation techniques. Future research should focus on the implementation of the $\mathrm{Hg}$ resistant microorganisms to remove or immobilise $\mathrm{Hg}$ from soil. Since each contaminated site has unique characteristics, a detailed evaluation and proper risk assessment should be carried out before implementing bioremediation. However, in addition to $\mathrm{Hg}$, contaminated sites are often polluted with a range of heavy metals and organic substances. Therefore, there is a need to isolate or genetically modify and characterize multi-metal resistant bacterial strains which have resistance to mixed contaminants in soil. As the leachability and bioavailability of $\mathrm{Hg}$ in soil is often negligible, bioremediation can be coupled with other techniques which can extract $\mathrm{Hg}$ from soil ligands that will be subjected to microbial volatilization and/or precipitation.

\section{Acknowledgement}


The authors acknowledge the support from Global Centre for Environmental Remediation, Faculty of Science and Information Technology, The University of Newcastle in collaboration with the Cooperative Research Centre for Contamination Assessment and Remediation of the Environment (CRC-CARE).

Compliance with ethical standards This article does not contain any studies with human participants or animals performed by any of the authors.

Conflict of interest The authors declare that they have no conflict of interest. 


\section{References}

Abumaizar RJ, Smith EH (1999) Heavy metal contaminants removal by soil washing. J Hazard Mater. 70:71-86 doi:http://dx.doi.org/10.1016/S0304-3894(99)00149-1

Adeniji A (2004) Bioremediation of arsenic, chromium, lead, and mercury. USEPA. http://nepis.epa.gov/Exe/

Ahluwalia SS, Goyal D (2007) Microbial and plant derived biomass for removal of heavy metals from wastewater. Bioresource Technol 98:2243-2257 doi:http://dx.doi.org/10.1016/j.biortech.2005.12.006

Amos HM, Jacob DJ, Streets DG, Sunderland EM (2013) Legacy impacts of all-time anthropogenic emissions on the global mercury cycle. Global Biogeochem Cy 27:410-421

Andréa M, Nascimento, Chartone-Souza E (2003) Operon mer: Bacterial resistance to mercury and potential for bioremediation of contaminated environments. Genet. Mol. Res. 2:92-101

Anthony E (2014) Bioremediation of mercury by biofilm forming mercury resistant marine bacteria. National Institute Of Technology Rourkela

Ariya PA Amyot M, Dastoor A, Deeds D, Feinberg A, Kos G, Poulain A, Ryjkov A, Semenjuk K, Subir M (2015) Mercury physicochemical and biogeochemical transformation in the atmosphere and at atmospheric interfaces: A review and future directions. Chem Rev 115:3760-3802

Asasian N, Kaghazchi T, Soleimani M (2012) Elimination of mercury by adsorption onto activated carbon prepared from the biomass material. J Ind Eng Chem 18:283-289

ATSDR (2015) Priority List of Hazardous Substances, Agency for Toxic Substances and Disease Registry (ATSDR).

Barkay T, Gillman M, Turner RR (1997) Effects of dissolved organic carbon and salinity on bioavailability of mercury. Appl Environ Microbiol 63:4267-4271

Barkay T, Kritee K, Boyd E, Geesey G (2010) A thermophilic bacterial origin and subsequent constraints by redox, light and salinity on the evolution of the microbial mercuric reductase. Environ Microbiol 12:2904-2917 doi:10.1111/j.1462-2920.2010.02260.x

Barkay T, Wagner-Döbler I (2005) Microbial Transformations of Mercury: Potentials, Challenges, and Achievements in Controlling Mercury Toxicity in the Environment. In: Allen I. Laskin JWB, Geoffrey MG (eds). Adv Appl Microbio, vol Volume 57. Academic Press, pp 1-52. doi:http://dx.doi.org/10.1016/S0065-2164(05)57001-1

BáStockwell P, TáCorns W (1995) Automated technique for mercury determination at sub-nanogram per litre levels in natural waters. J Anal Atom Spectrom 10:287-291

Bogdanova E, Bass IS, Minakhin LS, Petrova MA, Mindlin SZ, Volodin AA, Kalyaeva ES, Tiedj, JM, Hobman JL, Brown NL (1998) Horizontal spread of mer operons among Gram-positive bacteria in natural environments. Microbiology 144:609-620

Bontidean I, Mortari A, Leth S, Brown NL, Karlson U, Larsen MM, Vangronsveld J, Corbisier P, Csöregi E (2004) Biosensors for detection of mercury in contaminated soils. Environ Pollut 131:255-262

Bower J, Savage KS, Weinman B, Barnett MO, Hamilton WP, Harper WF (2008) Immobilization of mercury by pyrite $\left(\mathrm{FeS}_{2}\right)$ Environ Pollut 156:504-514

Brim H, McFarlan SC, Fredrickson JK, Minton KW, Zhai M, Wackett LP, Daly MJ (2000) Engineering Deinococcus radiodurans for metal remediation in radioactive mixed waste environments. Nature Biotechnol 18:85-90

Brim H, Venkateswaran A, Kostandarithes HM, Fredrickson JK, Daly MJ (2003) Engineering Deinococcus geothermalis for bioremediation of high-temperature radioactive waste environments Appl Environ Microbiol 69:4575-4582

Brown NL (1985) Bacterial resistance to mercury-reductio ad absurdum. Trend Biochem Sci 10:400-403

Busto Y, Cabrera X, Tack FMG, Verloo MG (2011) Potential of thermal treatment for decontamination of mercury containing wastes from chlor-alkali industry. J Hazard Mater 186:114-118 doi:http://dx.doi.org/10.1016/j.jhazmat.2010.10.099

Cabral L, Giovanella P, Gianello C, Bento FM, Andreazza R, Camargo FAO (2013) Isolation and characterization of bacteria from mercury contaminated sites in Rio Grande do Sul, Brazil, and assessment of methylmercury removal capability of a Pseudomonas putida V1 strain Biodegradation 24:319-331

Celo V, Lean DRS, Scott SL (2006) Abiotic methylation of mercury in the aquatic environment. Sci Total Environ 368:126-137. doi:http://dx.doi.org/10.1016/j.scitotenv.2005.09.043

Chien M, Nakahata R, Ono T, Miyauchi K, Endo G (2012) Mercury removal and recovery by immobilized Bacillus megaterium MB1. Frontiers of Chemical Science and Engineering 6:192-197

Cho JH, Eom Y, Lee TG (2014a) Pilot-test of the calcium sodium phosphate (CNP) process for the stabilization/solidification of various mercury-contaminated wastes. Chemosphere 117:374-381 
Cho JH, Eom Y, Lee TG (2014b) Stabilization/solidification of mercury-contaminated waste ash using calcium sodium phosphate (CNP) and magnesium potassium phosphate (MKP) processes. J Hazard Mater 278:474-482

Corbisier P, Thiry E, Masolijn A, Diels L (1994) Construction and development of metal ion biosensors Bioluminescence and chemiluminescence: fundamentals and applied aspects Wiley, Chichester:151155

Curran T, Franza Jr B (1991) Structure of the detoxification catalyst mercuric ion reductase from Bacillus sp. strain RC607. Nature 352:11

Cyr PJ, Suri RP, Helmig ED (2002) A pilot scale evaluation of removal of mercury from pharmaceutical wastewater using granular activated carbon. Water Res 36:4725-4734

Daly MJ, Ouyang L, Fuchs P, Minton KW (1994) In vivo damage and recA-dependent repair of plasmid and chromosomal DNA in the radiation-resistant bacterium Deinococcus radiodurans. J Bacteriol 176:3508-3517

Dash HR, Das S (2012) Bioremediation of mercury and the importance of bacterial mer genes. Int Biodeter Biodegr 75:207-213 doi:http://dx.doi.org/10.1016/j.ibiod.2012.07.023

Dash HR, Das S (2015) Bioremediation of inorganic mercury through volatilization and biosorption by transgenic Bacillus cereus BW-03 (p PW-05). Int Biodeter Biodegr 103:179-185

de Vries W, Lofts S, Tipping E, Meili M, Groenenberg JE, Schütze G (2007) Impact of soil properties on critical concentrations of cadmium, lead, copper, zinc, and mercury in soil and soil solution in view of ecotoxicological effects. In: Rev Environ Contam T. Springer, pp 47-89

Deckwer WD, Becker FU, Ledakowicz S, Wagner-Döbler I (2004) Microbial Removal of Ionic Mercury in a Three-Phase Fluidized Bed Reactor. Environ Sci Technol 38:1858-1865 doi:10.1021/es0300517

Dermont G, Bergeron M, Mercier G, Richer-Laflèche M (2008a) Metal-Contaminated Soils: Remediation Practices and Treatment Technologies Practice. Periodical of Hazardous, Toxic \& Radioactive Waste Management 12:188-209 doi:10.1061/(ASCE)1090-025X(2008)12:3(188)

Dermont G, Bergeron M, Mercier G, Richer-Laflèche M (2008b) Soil washing for metal removal: A review of physical/chemical technologies and field applications. J Hazard Mater152:1-31 doi:http://dx.doi.org/10.1016/j.jhazmat.2007.10.043

Dunham-Cheatham S, Mishra B, Myneni S, Fein JB (2015) The effect of natural organic matter on the adsorption of mercury to bacterial cells. Geochim Cosmochim Ac 150:1-10

EPA (2016). https://www.epa.gov/ground-water-and-drinking-water/table-regulated-drinking-watercontaminants\#Inorganic.

Essa A, Creamer N, Brown N, Macaskie L (2006) A new approach to the remediation of heavy metal liquid wastes via off-gases produced by Klebsiella pneumoniae M426. Biotechnol Bioeng 95:574-583

Felske AD, Fehr W, Pauling BV, Von Canstein H, Wagner-Döbler I (2003) Functional profiling of mercuric reductase (mer A) genes in biofilm communities of a technical scale biocatalyzer. BMC Microbiol 3:22

Findlay DM, McLean RA (1979) Treatment of mercury contaminated aqueous media. https://www.google.com/patents/US4147626

Fitzgerald WF, Lamborg CH (2007) Geochemistry of Mercury in the Environment. In: Heinrich DH, Karl KT (eds) Treatise on Geochemistry. Pergamon, Oxford, pp 1-47. doi:http://dx.doi.org/10.1016/B0-08043751-6/09048-4

Fleming EJ, Mack EE, Green PG, Nelson DC (2006) Mercury Methylation from Unexpected Sources: Molybdate-Inhibited Freshwater Sediments and an Iron-Reducing Bacterium. Appl Environ Microbiol 72:457-464 doi:10.1128/AEM.72.1.457-464.2006

François F, Lombard C, Guigner JM, Soreau P, Brian-Jaisson F, Martino G, Vandervennet M, Garcia D, Molinier AL, Pignol D (2012) Isolation and characterization of environmental bacteria capable of extracellular biosorption of mercury. Appl Environ Microbiol 78:1097-1106

Gårdfeldt K, Munthe J, Strömberg D, Lindqvist O (2003) A kinetic study on the abiotic methylation of divalent mercury in the aqueous phase Sci Total Environ 304:127-136 doi:http://dx.doi.org/10.1016/S00489697(02)00562-4

Giri S, Dash HR, Das S (2014) Mercury resistant bacterial population and characterization of Bacillus sp., isolated from sediment of solid waste discharged point of steel industry. Natl Acad Sci Lett 37:237-243 doi:10.1007/s40009-014-0229-4

Griffin HG, Foster TJ, Silver S, Misra TK (1987) Cloning and DNA sequence of the mercuric-and organomercurial-resistance determinants of plasmid pDU1358. P Natl A Sci 84:3112-3116

Guo X, Liu C, Zhu Z, Wang Z, Li J (2011) Evaluation methods for soil heavy metals contamination: A review. Chinese J Ecol 30:889\&896

Hadavifar M, Bahramifar N, Younesi H, Li Q (2014) Adsorption of mercury ions from synthetic and real wastewater aqueous solution by functionalized multi-walled carbon nanotube with both amino and thiolated groups. Chem Eng J 237:217-228 
Hakkila K, Green T, Leskinen P, Ivask A, Marks R, Virta M (2004) Detection of bioavailable heavy metals in EILATox-Oregon samples using whole-cell luminescent bacterial sensors in suspension or immobilized onto fibre-optic tips. J Appl Toxicol 24:333-342 doi:10.1002/jat.1020

Hakkila K, Maksimow M, Karp M, Virta M (2002) Reporter Genes lucFF, luxCDABE, gfp, and dsred Have Different Characteristics in Whole-Cell Bacterial Sensors. Anal Biochem 301:235-242

Hansen C, Stevens D (1993) Biological and Physio-Chemical Remediation of Mercury-Contaminated Hazardous Waste. Pollut Technol Rev 214:54-54

Hansen LH, Sørensen SJ (2000) Versatile biosensor vectors for detection and quantification of mercury. FEMS Microbiol Lett 193:123-127 doi:10.1111/j.1574-6968.2000.tb09413.x

Harris HH, Pickering IJ, George GN (2003) The chemical form of mercury in fish. Science 301:1203-1203

Heaton AC, Rugh CL, Kim T, Wang NJ, Meagher RB (2003) Toward detoxifying mercury-polluted aquatic sediments with rice genetically engineered for mercury resistance. Environ Toxicol Chem 22:29402947

Hintelmann H, Keppel-Jones K, Evans RD (2000) Constants of mercury methylation and demethylation rates in sediments and comparison of tracer and ambient mercury availability. Environ Toxicol Chem 19:22042211

Inoue C, Sugawara K, Kusano T (1991) The merR regulatory gene in Thiobacillus ferrooxidans is spaced apart from the mer structural genes. Mol Microbiol 5:2707-2718

Ivask A, Green T, Polyak B, Mor A, Kahru A, Virta M, Marks R (2007) Fibre-optic bacterial biosensors and their application for the analysis of bioavailable $\mathrm{Hg}$ and $\mathrm{As}$ in soils and sediments from Aznalcollar mining area in Spain. Biosens Bioelectron 22:1396-1402 doi:http://dx.doi.org/10.1016/j.bios.2006.06.019

Ivask A, Virta M, Kahru A (2002) Construction and use of specific luminescent recombinant bacterial sensors for the assessment of bioavailable fraction of cadmium, zinc, mercury and chromium in the soil. Soil Biol Biochem 34:1439-1447 doi:http://dx.doi.org/10.1016/S0038-0717(02)00088-3

Iwahori K, Takeuchi F, Kamimura K, Sugio T (2000) Ferrous iron-dependent volatilization of mercury by the plasma membrane of Thiobacillus ferrooxidans. Appl Environ Microbiol 66:3823-3827

Jafari SA, Cheraghi S, Mirbakhsh M, Mirza R, Maryamabadi A (2015) Employing response surface methodology for optimization of mercury bioremediation by Vibrio parahaemolyticus PG02 in coastal sediments of Bushehr, Iran CLEAN-Soil, Air, Water 43:118-126

Jamoussi B, Zafaouf M, Hassine BB (1995) Hydride generation/condensation system with an inductively coupled argon plasma polychromator for simultaneous determination of arsenic, antimony, selenium, lead, mercury and tin in honey. Int J Environ Anal Chem 61:249-256

Kalb P, Adams J, Milian L (2001) Sulfur Polymer Stabilization/Solidification (SPSS) Treatment of MixedWaste Mercury Recovered from Environmental Restoration Activities at BNL BNL-52614, January

Kelly D, Budd K, Lefebvre DD (2006) Mercury analysis of acid-and alkaline-reduced biological samples: Identification of meta-cinnabar as the major biotransformed compound in algae. Appl Environ Microbiol 72:361-367

Kelly DJ, Budd K, Lefebvre DD (2007) Biotransformation of mercury in pH-stat cultures of eukaryotic freshwater algae. Arch Microbiol 187:45-53

Kholodii GY, Yurieva O, Lomovskaya O, Gorlenko ZM, Mindlin S, Nikiforov V (1993) Tn5053, a mercury resistance transposon with integron's ends. J Mol Biol 230:1103-1107

Kostal J, Mulchandani A, Gropp KE, Chen W (2003) A temperature responsive biopolymer for mercury remediation. Environ Sci Technol 37:4457-4462

Kot FS, Rapoport VL, Kharitonova GV (2007) Immobilization of soil mercury by colloidal sulphur in the laboratory experiment. Cent Eur J Chem 5:846-857

Lappalainen JO, Karp MT, Nurmi J, Juvonen R, Virta MPJ (2000) Comparison of the total mercury content in sediment samples with a mercury sensor bacteria test and Vibrio Fischeri toxicity test. Environ Toxicol 15:443-448 doi:10.1002/1522-7278(2000)15:5<443::AID-TOX12>3.0.CO;2-L

Le TY, Zimmermann S, Sures B (2016) How does the metallothionein induction in bivalves meet the criteria for biomarkers of metal exposure? Environ Pollut 212:257-268

Lefebvre DD, Kelly D, Budd K (2007) Biotransformation of Hg (II) by cyanobacteria. Appl Environ Microbiol 73:243-249

Li Y, Murphy P, Wu C-Y (2008) Removal of elemental mercury from simulated coal-combustion flue gas using a SiO2-TiO2 nanocomposite. Fuel Process Technol 89:567-573 doi:http://dx.doi.org/10.1016/j.fuproc.2007.10.009

Liebert CA, Hall RM, Summers AO (1999) Transposon Tn21, flagship of the floating genome. Microbiol Mol Biol R 63:507-522

López FA, Alguacil FJ, Rodríguez O, Sierra MJ, Millán R (2015) Mercury leaching from hazardous industrial wastes stabilized by sulfur polymer encapsulation. Waste Manage 35:301-306 
Ma F, Zhang Q, Xu D, Hou D, Li F, Gu Q (2014a) Mercury removal from contaminated soil by thermal treatment with $\mathrm{FeCl} 3$ at reduced temperature. Chemosphere 117:388-393 doi:http://dx.doi.org/10.1016/j.chemosphere.2014.08.012

Ma F, Zhang Q, Xu D, Hou D, Li F, Gu Q (2014b) Mercury removal from contaminated soil by thermal treatment with $\mathrm{FeCl} 3$ at reduced temperature. Chemosphere 117:388-393

Ma W, Zhang M, Wang R, Xin B, Guo W, Dai J (2015) Mercury (II) Adsorption on Three Contrasting Chinese Soils Treated with Two Sources of Dissolved Organic Matter: II. Spectroscopic Characterization. Soil and Sediment Contamination: An International Journal 24:719-730

Mahbub KR, Krishnan K, Megharaj M, Naidu R (2016a) Bioremediation potential of a highly mercury resistant bacterial strain Sphingobium SA2 isolated from contaminated soil. Chemosphere 144:330-337

Mahbub KR, Krishnan K, Megharaj M, Naidu R (2016b) Mercury inhibits soil enzyme activity in a lower concentration than the guideline value. Bull Environ Contam Toxicol 96:76 - 82 doi:10.1007/s00128015-1664-8

Mahbub KR, Krishnan K, Naidu R, Andrews S, Megharaj M (2016c) Mercury toxicity to terrestrial biota. Ecol Indic doi:http://dx.doi.org/10.1016/j.ecolind.2016.12.004

Mahbub KR, Krishnan K, Naidu R, Megharaj M (2016d) Mercury remediation potential of a mercury resistant strain Sphingopyxis sp. SE2 isolated from contaminated soil. J Environ Sci doi:http://dx.doi.org/10.1016/j.jes.2016.06.032

Mahbub KR, Krishnan K, Naidu R, Megharaj M (2016e) Mercury resistance and volatilization by Pseudoxanthomonas sp. SE1 isolated from soil. Environ Technol Innovat 6:94-104 doi:10.1016/j.eti.2016.08.001

Mahbub KR, Subashchandrabose SR, Krishnan K, Naidu R, Megharaj M (2016f) Mercury alters the bacterial community structure and diversity in soil even at concentrations lower than the guideline values. Appl Microbiol Biotechnol:1-13 doi:10.1007/s00253-016-7965-y

Marrugo-Negrete J, Enamorado-Montes G, Durango-Hernández J, Pinedo-Hernández J, Díez S (2017) Removal of mercury from gold mine effluents using Limnocharis flava in constructed wetlands. Chemosphere 167:188-192 doi:10.1016/j.chemosphere.2016.09.130

Mason RP, Fitzgerald WF, Morel FM (1994) The biogeochemical cycling of elemental mercury: anthropogenic influences. Geochim Cosmochim Ac 58:3191-3198

Mattigod S, Fryxell G, Parker K (2007) A thiol-functionalized nanoporous silica sorbent for removal of mercury from actual industrial waste. Environmental applications of nanomaterials: synthesis, sorbents and sensors: 275

Minu M, Kumar N, Shilpa J (2015) Role of Gymnemic Acid-Chitosan Nanoparticles in Mercury Removal from Water. J Chitin Chitosan Sci 3:68-76

Misra TK, Brown NL, Fritzinger DC, Pridmore RD, Barnes WM, Haberstroh L, Silver S (1984) Mercuric ionresistance operons of plasmid R100 and transposon Tn501: the beginning of the operon including the regulatory region and the first two structural genes Proceedings of the National Academy of Sciences 81:5975-5979

Mulligan CN, Yong RN, Gibbs BF (2001) An evaluation of technologies for the heavy metal remediation of dredged sediments. J Hazard Mater 85:145-163 doi:http://dx.doi.org/10.1016/S0304-3894(01)00226-6

Munthe J (1992) The aqueous oxidation of elemental mercury by ozone. Atmos Environ A - Gen 26:1461-1468

Munthe J, McElroy W (1992) Some aqueous reactions of potential importance in the atmospheric chemistry of mercury. Atmos Environ A-Gen 26:553-557

Munthe J, Xiao Z, Lindqvist O (1991) The aqueous reduction of divalent mercury by sulfite. Water Air Soil Poll 56:621-630

Musmarra D, Karatza D, Lancia A, Prisciandaro P, Mazziotti di Celso G (2013) Adsorption of mercury chloride onto activated carbon on a new pilot scale plant. Chemical Engineering Transactions 32:547-552

Nakamura K, Hagimine M, Sakai M, Furukawa K (1999) Removal of mercury from mercury-contaminated sediments using a combined method of chemical leaching and volatilization of mercury by bacteria. Biodegradation 10:443-447

Nascimento AM, Chartone-Souza E (2003) Operon mer: bacterial resistance to mercury and potential for bioremediation of contaminated environments. Gen Mol Res 2:92-101

Nelson PF, Morrison AL, Malfroy HJ, Cope M, Lee S, Hibberd ML, Meyer CP, McGregor J (2012) Atmospheric mercury emissions in Australia from anthropogenic, natural and recycled sources. Atmos Environ 62:291-302

Nies DH (1999) Microbial heavy-metal resistance. Appl Microbiol Biotechnol 51:730-750

Nucifora G, Silver S, Misra TK (1989) Down regulation of the mercury resistance operon by the most promoterdistal gene merD. Mol Gen Genet MGG 220:69-72

O'rear DJ, Cooper RE, Yean S, Gallup DL, Young LA (2015) Process, method, and system for removing mercury from fluids. https://www.google.com/patents/US7666318. 
Oehmen A, Vergel D, Fradinho J, Reis MA, Crespo JG, Velizarov S (2014) Mercury removal from water streams through the ion exchange membrane bioreactor concept. J hazard Mater 264:65-70

Ojea-Jiménez I, López X, Arbiol J, Puntes V (2012) Citrate-coated gold nanoparticles as smart scavengers for mercury (II) removal from polluted waters. ACS nano 6:2253-2260

Osborn AM, Bruce KD, Strike P, Ritchie DA (1997) Distribution, diversity and evolution of the bacterial mercury resistance (mer) operon. FEMS Microbiolo Revi 19:239-262 doi:10.1111/j.15746976.1997.tb00300.x

Pant P, Allen M, Tansel B (2010) Mercury Uptake and Translocation in Impatiens walleriana Plants Grown in the Contaminated Soil from Oak Ridge. Int J Phytoremediat 13:168-176

Patterson J, Stein L (1997) Capsule Report: Aqueous Mercury Treatment NASA

Pepi M, Focardi S, Tarabelli A, Volterrani M, Focardi S Bacterial strains resistant to inorganic and organic forms of mercury isolated from polluted sediments of the Orbetello Lagoon, Italy, and their possible use in bioremediation processes. In: E3S Web of Conferences, 2013. EDP Sciences, p 31002

Pepi M, Gaggi C, Bernardini E, Focardi S, Lobinaco A, Ruta M, Nicolardi V, Volterrani M, Gasperini S, Trinchera G (2011) Mercury-resistant bacterial strains Pseudomonas and Psychrobacter spp. isolated from sediments of Orbetello Lagoon (Italy) and their possible use in bioremediation processes. Int Biodet Biodeg 65:85-91

Piao H, Bishop PL (2006) Stabilization of mercury-containing wastes using sulfide. Environ Pollut 139:498-506

Pirrone N, Cinnirella S, Feng X, Finkelman RB, Friedli HR, Leaner J, Mason R, Mukherjee AB, Stracher GB, Streets DG (2010) Global mercury emissions to the atmosphere from anthropogenic and natural sources. Atmos Chem Phys 10:5951-5964

Priyadarshi H, Alam A, Gireesh-Babu P, Das R, Kishore P, Kumar S, Chaudhari A (2012) A GFP-based bacterial biosensor with chromosomally integrated sensing cassette for quantitative detection of $\mathrm{Hg}$ (II) in environment. J Environ Sci 24:963-968 doi:http://dx.doi.org/10.1016/S1001-0742(11)60820-6

Rådström P, Sköld O, Swedberg G, Flensburg J, Roy PH, Sundström L (1994) Transposon Tn5090 of plasmid $\mathrm{R} 751$, which carries an integron, is related to $\mathrm{Tn} 7, \mathrm{Mu}$, and the retroelements. J Bacteriol 176:32573268

Rasmussen LD, Sørensen SJ, Turner RR, Barkay T (2000) Application of a mer-lux biosensor for estimating bioavailable mercury in soil. Soil Biol Biochem 32:639-646

Rasmussen LD, Turner RR, Barkay T (1997) Cell-density-dependent sensitivity of a mer-lux bioassay. Appl Environ Microbiol 63:3291-3293

Rojas LA, Yáñez C, González M, Lobos S, Smalla K, Seeger M (2011) Characterization of the metabolically modified heavy metal-resistant Cupriavidus metallidurans strain MSR33 generated for mercury bioremediation. PloS one 6:e17555

Ruiz O, Alvarez D, Gonzalez-Ruiz G, Torres C (2011) Characterization of mercury bioremediation by transgenic bacteria expressing metallothionein and polyphosphate kinase. BMC Biotechnol 11:82

Santos-Gandelman JF, Giambiagi-deMarval M, Muricy G, Barkay T, Laport MS (2014) Mercury and methylmercury detoxification potential by sponge-associated bacteria. A van Leeuw J Microb 106:585590

Sar P, Kazy S, Paul D, Sarkar A (2013) Metal Bioremediation by Thermophilic Microorganisms. In: Satyanarayana T, Littlechild J, Kawarabayasi Y (eds) Thermophilic Microbes in Environmental and Industrial Biotechnology. Springer Netherlands, pp 171-201. doi:10.1007/978-94-007-5899-5_6

Schottel J (1978) The mercuric and organomercurial detoxifying enzymes from a plasmid-bearing strain of Escherichia coli. J Biolo Chem 253:4341-4349

Selifonova O, Burlage R, Barkay T (1993) Bioluminescent sensors for detection of bioavailable Hg (II) in the environment Appl Enviro Microbiol 59:3083-3090

Serrano O, Martínez-Cortizas A, Mateo M, Biester H, Bindler R (2013) Millennial scale impact on the marine biogeochemical cycle of mercury from early mining on the Iberian Peninsula. Global Biogeochem Cy 27:21-30

Silver S, Phung LT (1996) Bacterial heavy metal resistance: new surprises. Annu Rev Microb 50:753-789

Singh JS, Abhilash PC, Singh HB, Singh RP, Singh DP (2011) Genetically engineered bacteria: An emerging tool for environmental remediation and future research perspectives. Gene 480:1-9 doi:http://dx.doi.org/10.1016/j.gene.2011.03.001

Sinha A, Khare SK (2011) Mercury bioaccumulation and simultaneous nanoparticle synthesis by Enterobacter sp. Cells. Bioresource Technol 102:4281-4284

Sinha A, Khare SK (2012) Mercury bioremediation by mercury accumulating Enterobacter sp. cells and its alginate immobilized application. Biodegradation 23:25-34

Sinha A, Pant KK, Khare SK (2012) Studies on mercury bioremediation by alginate immobilized mercury tolerant Bacillus cereus cells. Int Biodet Biodeg 71:1-8 doi:http://dx.doi.org/10.1016/j.ibiod.2011.12.014 
Skyllberg U (2012) Chemical speciation of mercury in soil and sediment. Environmental Chemistry and Toxicology of Mercury. John Wiley \& Sons, Inc.,

Skyllberg U, Bloom PR, Qian J, Lin C-M, Bleam WF (2006) Complexation of mercury (II) in soil organic matter: EXAFS evidence for linear two-coordination with reduced sulfur groups. Environ Sci Technol 40:4174-4180

Smolinska B (2015) Green waste compost as an amendment during induced phytoextraction of mercurycontaminated soil. Environ Sci Pollut R 22:3528-3537 doi:10.1007/s11356-014-3601-5

Stein ED, Cohen Y, Winer AM (1996) Environmental distribution and transformation of mercury compounds Critical Reviews in Environ Sci Technol 26:1-43

Su Y, Han FX, Chen J, Sridhar BM, Monts DL (2008) Phytoextraction and accumulation of mercury in three plant species: Indian mustard (Brassica juncea), beard grass (Polypogon monospeliensis), and Chinese brake fern (Pteris vittata). Int J Phytoremediat 10:547-560

Su Y, Shiyab S, Monts D Phytoextraction and Accumulation of Mercury in Selected Plant Species Grown in Soil Contaminated with Different Mercury Compounds. In: WM 2007, 2007.

Summer A, Silver S (1978) Microbial transformation of metals. Annu Rev Microbiol 32:37-672

Summers AO (1986) Organization, expression, and evolution of genes for mercury resistance. Annu Rev Microbiol 40:607-634

Summers AO, Lewis E (1973) Volatilization of mercuric chloride by mercury-resistant plasmid-bearing strains of Escherichia coli, Staphylococcus aureus, and Pseudomonas aeruginosa. J Bacteriol 113:1070-1072

Tangahu BV, Sheikh Abdullah SR, Basri H, Idris M, Anuar N, Mukhlisin M (2011) A review on heavy metals (As, $\mathrm{Pb}$, and $\mathrm{Hg}$ ) uptake by plants through phytoremediation. Int J Chem Eng 2011

Tariq A, Latif Z (2014) Bioremediation of Mercury Compounds by using Immobilized Nitrogen-fixing Bacteria. Int J Agric Biol 16

Tazisong IA, Senwo ZN, Williams MI (2012) Mercury speciation and effects on soil microbial activities. J Environ Sci Heal A 47:854-862

Tipping E, Lofts S, Hooper H, Frey B, Spurgeon D, Svendsen C (2010) Critical limits for Hg (II) in soils, derived from chronic toxicity data. Environ Pollut 158:2465-2471

Turdean GL (2011) Design and development of biosensors for the detection of heavy metal toxicity. Int J Electrochem 2011

Turyan I, Mandler D (1993) Electrochemical mercury detection. Nature 362:703-704

Urgun-Demirtas M, Benda PL, Gillenwater PS, Negri MC, Xiong H, Snyder SW (2012) Achieving very low mercury levels in refinery wastewater by membrane filtration. J Hazard Mater 215:98-107

USEPA (1997) Office of Research and Development. Capsule Report, Aqueous Mercury Treatment. EPA-625R-97-004. July.

USEPA (1998) Pump and Treat of Contaminated Groundwater at the King of Prussia Technical Corporation Superfund Site, Winslow Township, New Jersey.

USEPA (2000) Development Document for Final Effluent Limitations Guidelines and Standards for Commercial Hazardous Waste Combustors.

USEPA (2002) Arsenic Treatment Technologies for Soil, Waste, and Water. DIANE Publishing. http://www.dianepublishing.net/Arsenic_Treatment_Technologies_for_Soil_Waste_and_p/142890020 9.htm

USEPA (2007) Treatment Technologies for Mercury in Soil, Waste, and Water. https://www.epa.gov/remedytech/treatment-technologies-mercury-soil-waste-and-water

Velásquez-Riaño M, Benavides-Otaya HD (2015) Bioremediation techniques applied to aqueous media contaminated with mercury. Crit Rev Biotechnol:1-7

Wagner-Döbler I (2003) Pilot plant for bioremediation of mercury-containing industrial wastewater. Appl Microbiol Biotechnol 62:124-133 doi:10.1007/s00253-003-1322-7

Wagner-Döbler I (2013) Bioremediation of Mercury: Current Research and Industrial Applications. Horizon Scientific Press,

Wang J, Feng X, Anderson CW, Xing Y, Shang L (2012) Remediation of mercury contaminated sites-a review J Hazard Mater 221:1-18

Wang Q, Kim D, Dionysiou DD, Sorial GA, Timberlake D (2004) Sources and remediation for mercury contamination in aquatic systems - a literature review Environ Pollut 131:323-336 doi:http://dx.doi.org/10.1016/j.envpol.2004.01.010

Wang Y, Stauffer C, Keller C, Greger M (2005) Changes in Hg fractionation in soil induced by willow. Plant and Soil 275:67-75 doi:10.1007/s11104-004-6108-x

Wiatrowski HA, Ward PM, Barkay T (2006a) Novel reduction of mercury (II) by mercury-sensitive dissimilatory metal reducing bacteria. Environ Sci Technol 40:6690-6696

Wiatrowski HA, Ward PM, Barkay T (2006b) Novel Reduction of Mercury(II) by Mercury-Sensitive Dissimilatory Metal Reducing Bacteria. Environ Sci Technol 40:6690-6696 doi:10.1021/es061046g 
Xiong Z, He F, Zhao D, Barnett MO (2009) Immobilization of mercury in sediment using stabilized iron sulfide nanoparticles. Water Rese 43:5171-5179 doi:http://dx.doi.org/10.1016/j.watres.2009.08.018

Xu J (2013) Feasibility study of soil washing to remediate mercury contaminated soil. http://ltu.divaportal.org/smash/record.jsf?pid=diva2\%3A991679\&dswid=_e_0ACH

Xu J, Bravo AG, Lagerkvist A, Bertilsson S, Sjöblom R, Kumpiene J (2015) Sources and remediation techniques for mercury contaminated soil. Environ Int 74:42-53

Xu J, Kleja DB, Biester H, Lagerkvist A, Kumpiene J (2014) Influence of particle size distribution, organic carbon, $\mathrm{pH}$ and chlorides on washing of mercury contaminated soil. Chemosphere 109:99-105

Zhang S, Zhang X, Xiong Y, Wang G, Zheng N (2015) Effective solidification/stabilisation of mercurycontaminated wastes using zeolites and chemically bonded phosphate ceramics. Waste Manage Res 33:183-190

Zhang T, Hsu-Kim H (2010) Photolytic degradation of methylmercury enhanced by binding to natural organic ligands. Nat Geosci 3:473-476

Zhuang JM, Lo T, Walsh T, Lam T (2004) Stabilization of high mercury contaminated brine purification sludge J Hazard Mater 113:157-164 
Table 1: Mercury remediation technologies

\begin{tabular}{|c|c|c|c|c|}
\hline Treatment & Matrix & Species & Mechanism & References \\
\hline \multicolumn{5}{|c|}{ Physico-chemical techniques } \\
\hline $\begin{array}{l}\text { Solidification and } \\
\text { stabilization }\end{array}$ & $\begin{array}{l}\text { Solid and } \\
\text { waste }\end{array}$ & $\begin{array}{l}\text { Elemental } \mathrm{Hg} \text { and } \\
\text { contaminated soil }\end{array}$ & $\begin{array}{l}\text { Reducing the mobility by physically binding within a stabilized } \\
\text { mass; or chemically converting into less soluble form }\end{array}$ & (López et al. 2015) \\
\hline Amalgamation & $\begin{array}{l}\text { Solid and } \\
\text { waste }\end{array}$ & Elemental Hg & Dissolution in other metals, formation of semi-solid alloy & (Kalb et al. 2001) \\
\hline Soil washing & $\begin{array}{l}\text { Soil and } \\
\text { sediment }\end{array}$ & Elemental Hg & $\begin{array}{l}\text { Washing the contaminated soil with a soil solution and treating the } \\
\text { water by ion exchange and solvent extraction }\end{array}$ & (Xu 2013) \\
\hline $\begin{array}{l}\text { Acid } \\
\text { extraction/chemical } \\
\text { leaching }\end{array}$ & $\begin{array}{l}\text { Soil and } \\
\text { sediment }\end{array}$ & Elemental Hg & Extraction by dissolving in acid followed by flocculation & (Xu et al. 2014) \\
\hline Thermal treatment & $\begin{array}{l}\text { Soil, sediment } \\
\text { and waste }\end{array}$ & Elemental Hg & $\begin{array}{l}\text { Volatilization by heating at reduced pressure followed by } \\
\text { condensation, then amalgamation }\end{array}$ & (Ma et al. 2014b) \\
\hline Vitrification & $\begin{array}{l}\text { Soil and } \\
\text { sediment }\end{array}$ & Elemental $\mathrm{Hg}$ & $\begin{array}{l}\text { Immobilization by incorporating in vitrified end products by high } \\
\text { temperature treatment }\end{array}$ & (USEPA 2002) \\
\hline Precipitation & Water & Inorganic $\mathrm{Hg}$ & $\begin{array}{l}\text { Transformation of dissolved } \mathrm{Hg} \text { in insoluble precipitates (sulphide } \\
\text { precipitation) }\end{array}$ & $\begin{array}{l}\text { (Patterson and Stein 1997) } \\
\text { (USEPA 2002) }\end{array}$ \\
\hline Adsorption & water & Inorganic $\mathrm{Hg}$ & $\begin{array}{l}\text { Reducing concentration by adsorption at the surface of a sorbent } \\
\text { packed in a column }\end{array}$ & $\begin{array}{l}\text { (Cyr et al. 2002; USEPA } \\
\text { 1998) }\end{array}$ \\
\hline $\begin{array}{l}\text { Membrane } \\
\text { filtration }\end{array}$ & water & Inorganic $\mathrm{Hg}$ & $\begin{array}{l}\text { Precipitation or co-precipitation followed by filtration through a } \\
\text { semi-permeable membrane }\end{array}$ & (USEPA 2000) \\
\hline \multicolumn{5}{|c|}{ Biological Techniques } \\
\hline Phytoremediation & $\begin{array}{l}\text { Sediments, } \\
\text { soil, water }\end{array}$ & Inorganic $\mathrm{Hg}$ & $\begin{array}{l}\text { Accumulation of } \mathrm{Hg} \text { in harvested plant; reduction of ionic } \mathrm{Hg} \text { to } \\
\text { elemental } \mathrm{Hg} \text { by engineered plant }\end{array}$ & $\begin{array}{l}\text { (Heaton et al. 2003; } \\
\text { Marrugo-Negrete et al. } \\
\text { 2017; Su et al. 2008) }\end{array}$ \\
\hline $\begin{array}{l}\text { Microbial } \\
\text { remediation }\end{array}$ & Water & Inorganic and organic $\mathrm{Hg}$ & $\begin{array}{l}\text { Transformation of highly toxic forms to less toxic elemental form } \\
\text { by microbial "Hg reductase" enzyme followed by volatilization }\end{array}$ & (Wagner-Döbler 2013) \\
\hline Biosorption & $\begin{array}{l}\text { Water, } \\
\text { sediment }\end{array}$ & Inorganic and organic $\mathrm{Hg}$ & $\begin{array}{l}\text { Adsorbing } \mathrm{Hg} \text { on biological material such as plant, algae, moss, } \\
\text { lichen, crab carapace, bacterial biofilm, fungal biomass etc. }\end{array}$ & (Wagner-Döbler 2013) \\
\hline \multicolumn{5}{|c|}{ Nanotechnology } \\
\hline $\begin{array}{l}\text { Use of different } \\
\text { nano-adsorbent }\end{array}$ & Water & Inorganic, organic $\mathrm{Hg}$ & $\begin{array}{l}\text { Thiol group containing nano-adsorbents, alumina nanoparticles etc } \\
\text { are being used to trap } \mathrm{Hg}\end{array}$ & $\begin{array}{l}\text { (Li et al. 2008; Mattigod et } \\
\text { al. 2007) }\end{array}$ \\
\hline
\end{tabular}


Table 2: Functional genes present in mer operon of mercury resistant bacteria (adapted from (Andréa et al. 2003; Dash and Das 2012; Osborn et al. 1997))

\begin{tabular}{|c|c|c|c|}
\hline Genes & Encoded protein & Location & Functions \\
\hline merA & Mercuric reductase & cytoplasm & Reduction of $\mathrm{Hg}^{2+}$ to $\mathrm{Hg}^{0}$ \\
\hline $\operatorname{mer} B$ & Organomercurial lyase & cytoplasm & Lysis of $\mathrm{C}-\mathrm{Hg}^{+}$bond \\
\hline $\operatorname{merC}$ & Mercuric ion transport protein & Inner membrane & Transport of $\mathrm{Hg}^{2+}$ \\
\hline merD & Regulatory Protein & cytoplasm & $\begin{array}{l}\text { Negatively regulates the mer } \\
\text { operon }\end{array}$ \\
\hline merE & MethylHg transport protein & Inner protein & $\begin{array}{l}\text { Uptake of organomercurials into } \\
\text { cytoplasm }\end{array}$ \\
\hline $\operatorname{mer} F$ & Mercuric ion transport protein & Inner membrane & Transport of $\mathrm{Hg}^{2+}$ \\
\hline $\operatorname{mer} G$ & Phenylmercury resistance protein & periplasm & $\begin{array}{l}\text { Resistance to phenylmercury by } \\
\text { efflux mechanism }\end{array}$ \\
\hline merP & $\begin{array}{l}\text { Periplasmic mercuric ion binding } \\
\text { protein }\end{array}$ & periplasm & $\begin{array}{l}\text { Transfer of } \mathrm{Hg}^{2+} \text { to integral } \\
\text { membrane protein }\end{array}$ \\
\hline merR & Regulatory protein & cytoplasm & Positively regulates the mer operon \\
\hline $\operatorname{mer} T$ & Mercuric ion transport protein & Inner membrane & Transport of $\mathrm{Hg}^{2+}$ \\
\hline
\end{tabular}

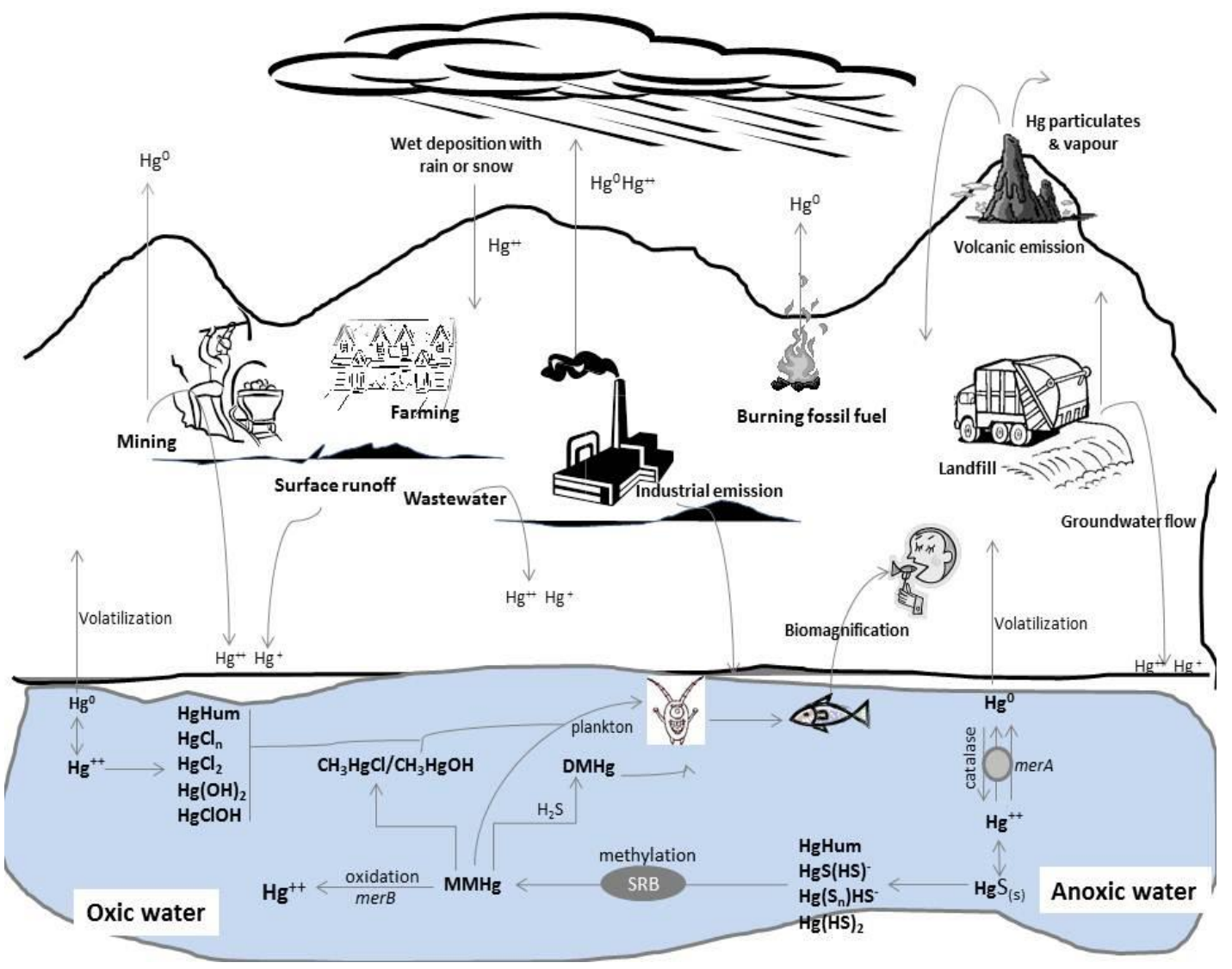

Figure 1: Emission and cycling of $\mathrm{Hg}$ in the environment; adapted from (Barkay and Wagner-Döbler 2005) 


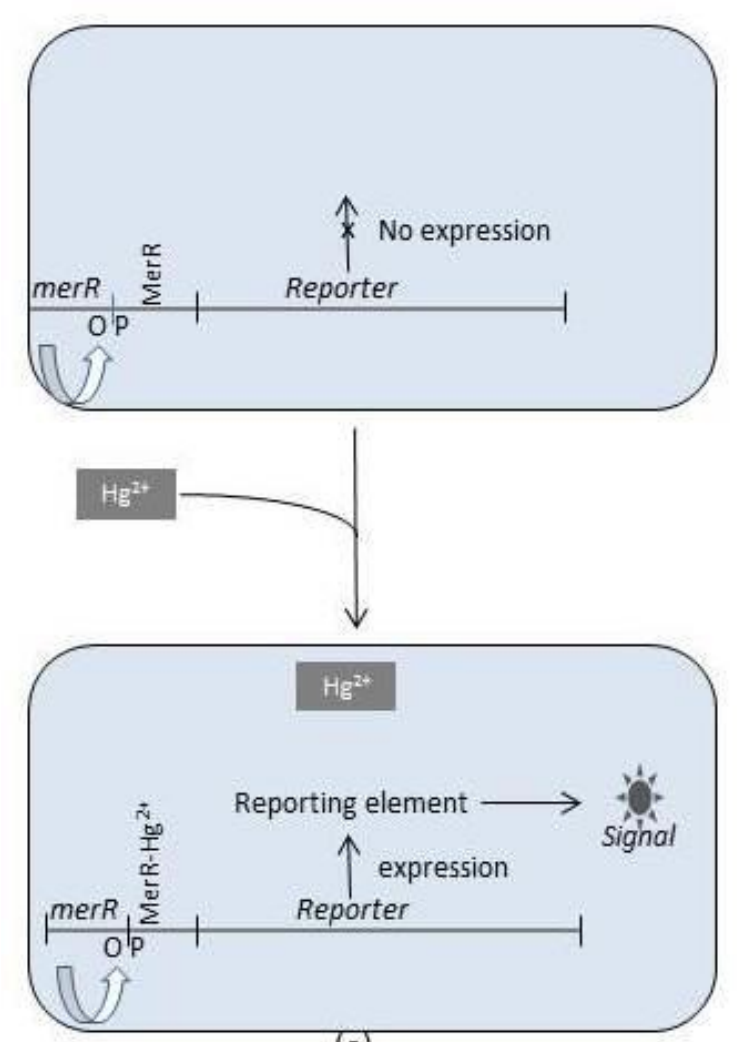

(a)

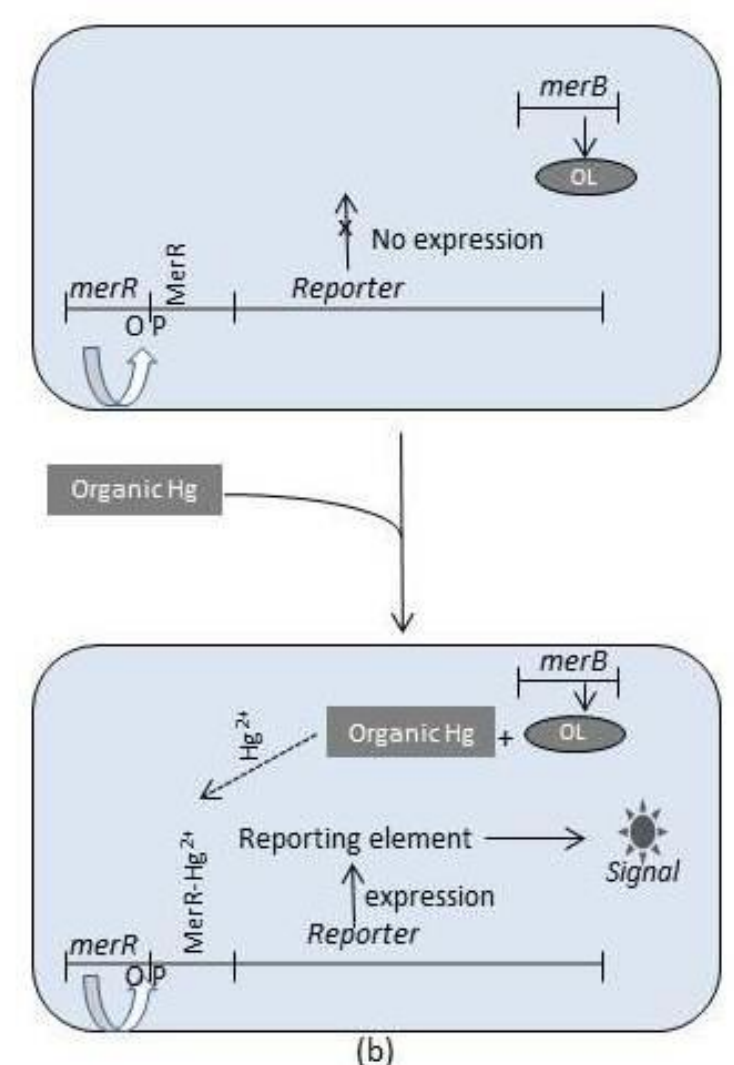

(b)

Figure 2: Schematic diagram of biochemical receptor in mercury biosensors (Barkay and Wagner-Döbler 2005): (a) when the biosensor comes into contact with $\mathrm{Hg}^{2+}$ it binds with the MerR protein having high affinity to $\mathrm{Hg}^{2+}$, repression is alleviated and the reporter gene is expressed resulting in a detectable signal. (b) for organic $\mathrm{Hg}$ detection, biosensors carry an additional gene $\operatorname{merB}$ encoding the enzyme organomercurial lyase (OL). In the presence of organic $\mathrm{Hg}$, the enzyme cleaves the $\mathrm{C}-\mathrm{Hg}$ bond to release $\mathrm{Hg}^{2+}$ which subsequently interacts with MerR to induce reporter gene expression. 